\title{
A comparison of Korean vowel formants in conditions of chanting and reading utterances*
}

\author{
Jihye Park ${ }^{1} \cdot$ Cheoljae Seong ${ }^{2 * *}$ \\ ${ }^{1}$ Speech-Language Pathology, Bombi and Sciat Speech Learning Psychology Center, Sejong, Korea \\ ${ }^{2}$ Linguistics, Chungnam National University, Daejeon, Korea
}

\begin{abstract}
Vowel articulation in subjects related to speech disorders seems to be difficult. A chant method that properly reflects the characteristics of language could be used as an effective way of addressing the difficulties. The purpose of this study was to find out whether the chant method is effective as a means of enhancing vowel articulation. The subjects of this study were 60 normal adults ( 30 males and 30 females) in their 20s and 30s whose native language is Korean. Eight utterance conditions including chanting and reading conditions were recorded and their acoustic data were analyzed. The results of the analysis of the acoustic variables related to the formant confirmed that the F1 and F2 values of the vowel formants are increased and the direction of movement of the center of gravity of the vowel triangle is statistically significantly forwarded and lowered in the chant method in both the word and the phrase context. The results also proved that accent is the most influential musical factor in chant. There was no significant difference between four repeated tokens, which increased the reliability of the results. In other words, chanting is an effective way to shift the center of gravity of the vowel triangle, which suggests that it can help to improve speech intelligibility by forming a desirable place for articulation.
\end{abstract}

Keywords: vowel formants, center of gravity, vowel triangle, chant

\section{1. 서론}

모음(vowel)은 음절(syllable)을 구성하는 데에 필수적인 성분 으로, 하나의 모음을 중심으로 앞뒤에 자음(들)이 결합하여 소 리단위를 형성한다(Kang, 2005). 보통의 발화에서 자음과 모음 을 결합한 음절 형태를 사용하는 것을 생각해보면 모음은 보다 정확한 조음을 하는 데에 있어 중요한 요소임을 알 수 있다. 음
향학적 차원에서 살펴보면, 모음은 성도(vocal tract)를 지나는 음원의 특정 주파수 에너지가 성도의 모양에 따라서 강화 또는 약화되어 입 밖으로 나오는 소리로 설명된다(Choi et al., 2015).

모음의 특성을 파악하기 위해 다양한 음향변수를 사용한다. 특히, 성도의 공명 주파수를 의미하는 포먼트는 일반적으로 모 음 분석에 효율적으로 사용되는데, 제 1 포먼트 $\left(F_{1}\right)$ 는 턱의 벌어 짐 정도에 따라 구강 공간을 넓히면 값이 커지고, 제 2포먼트

\footnotetext{
* This paper is revised and supplemented from the first author's 2020 master's thesis.

** cjseong49@gmail.com, Corresponding author

Received 27 June 2020; Revised 27 August 2020; Accepted 29 August 2020

(c) Copyright 2020 Korean Society of Speech Sciences. This is an Open-Access article distributed under the terms of the Creative Commons Attribution NonCommercial License (http://creativecommons.org/licenses/by-nc/4.0) which permits unrestricted non-commercial use, distribution, and reproduction in any medium, provided the original work is properly cited.
} 
$\left(F_{2}\right)$ 는 혀의 전후 움직임에 따라 혀가 앞쪽으로 향할 때 값이 커 지는 것으로 성도의 공명 특성을 파악할 수 있다(Fry, 1982). 그 외, 포먼트 대역폭, 모음 간 유클리드 거리, 모음 공간 면적, 모 음 삼각형 무게 중심, 포먼트 에너지 등이 사용된다 $(\mathrm{Kim} \&$ Seong, 2016; Seong, 2004).

모음은 발화 시 자음과 결합하여 인접한 자음의 조음에 영향 을 미칠 수 있다(Eom \& Shin, 2018). 따라서 정확한 조음위치를 찾고 적절한 구강개방을 이루어 모음을 조음하는 것이 정확한 말 산출을 위해 중요할 것이다. 그러나 언어병리 분야의 다양한 대상자들은 정확한 조음위치에서 말소리를 산출하는 것이 어 렵다. 특히, 구개열 말소리장애에서 많이 언급되는 보상적 오류 는 성문과 인두에서 만들어내는 파열음이나 마찰음 등 조음위 치의 극단적인 후방화를 특징으로 한다(Howard \& Lohmander, 2011; Kim \& Shin, 2015; Kummer, 2007). 청각장애인의 경우에 는 입 안의 중앙에서 모음을 조음하여 양극단에 있는 단모음 / 이/, /아/, /우/가 중앙화되는 특징이 있으며(Choi \& Seong, 2010), 말소리장애 아동은 모음이 자음과 동화되는 패턴으로 인해 조 음의 어려움을 보이기도 한다(Kim, 2014). 또한, 양질의 의사소 통을 요구하는 최근 사회적 배경의 관점에서 $\operatorname{Song}(2011)$ 은 대 화 시 입을 덜 벌리고 이야기하는 습관을 가진 화자의 경우 웅 얼거림이 답답한 인상을 주며, 잘 들리지 않는 말소리로 인해 되묻는 경우가 발생한다고 하였다.

조음치료는 타율적이고 기계적인 ‘훈련’의 차원에서 벗어나 능동적이고 자율적인 '학습’차원의 언어치료를 지향하는데 (Kwon \& Sim, 2001), 이와 관련하여 '노래 부르기'는 효과적인 도구가 될 수 있다. 노래는 기본주파수, 음높이 변화, 세기, 리듬 등의 요소를 언어와 공유하는 음악적 행위로서(Cohen, 1992), 언어를 사용할 때 필요한 음의 높낮이, 리듬, 빠르기, 강세 등의 특성을 적절히 반영하도록 도울 수 있다(Chung et al., 2006). 특 히 언어기능 회복을 위해 구조화된 움직임을 반복 연습 할 때 능동적인 노래 부르기는 긍정적인 기회를 제공할 수 있고 (Tamplin \& Denise, 2008), 과정에서의 즐거움을 통해 자발적인 참여와 동기부여가 가능하게 한다(Hong et al., 2010).

이에 본 연구에서는 노래 부르기 방법 중 하나인 챈트(chant) 를 제시하였다. 챈트는 하나의 단어 또는 짧은 문장을 비슷한 음도(pitch)에서 반복적으로 부르는 방법으로(Baker \& Uhlig, 2011), 단순한 구조로 인해 보다 쉽게 익히고 표현할 수 있다. 따 라서 챈트조건과 읽기조건의 발화에 따른 모음 특성을 비교하 여 모음 삼각형 무게중심 음향변수를 중심으로 포먼트의 이동 양상을 확인하고, 성별에 따른 차이, 발화길이(단어와 구)와 챈 트조건에 적용된 음악요소(악센트, 리듬) 간의 차이를 확인하고 자 한다.

\section{2. 연구 방법}

\section{1. 연구대상}

본 연구는 한국어를 모국어로 하는 20 30대 성인 60명(남 30 명, 여 30 명)을 대상으로 하였다. 대상자의 평균 연령은 27세(남
26세, 여 28세)였으며, 서울 및 충청권 거주자로서 고등학교 이 상의 학력에 말 - 언어장애가 없고 정상청력을 보유한 화자였다.

2.2. 연구절차

\subsection{1. 녹음 과정}

녹음은 방음부스 또는 소음이 적은 독립된 공간에서 진행되 었다. 대상자는 의자에 착석하여 이어폰을 착용하였고, 입과 마 이크의 거리를 약 $10 \sim 15 \mathrm{~cm}$ 로 유지하였다. 챈트 발성에서 사용 된 드럼비트는 소프트웨어 Garage Band에 내장된 'Modern Analog'를, 녹음기는 TASCAM DR-40X (TEAC, USA)를 사용하 였다(condition: 44,100 Hz sampling rate, 16 bit quantization, mono). 녹음 실시 전 대상자에게 자료를 제시한 뒤 읽기와 챈트 수행 에 대해 간단히 설명하였다. 읽기의 경우, 평소의 말하기 속도 로 자연스럽게 읽도록 안내하였고, 챈트는 드럼비트에 맞춰 편 안한 음높이로 과제를 표현하도록 하였으며, 1 2회의 연습을 통해 적절한 수행을 확인하였다. 이때 악보를 읽기 어려운 경우 에는 그림 상자를 보고 악센트 표시에서 세게, 한 칸에 한 박자 씩 맞춰 리듬을 표현하도록 하였다. 녹음 순서는 평소의 모음 발화 습관을 확인하기 위해 읽기조건을 먼저 녹음한 후 챈트조 건 녹음을 진행하였다. 각 조건에는 산출하는 발화 길이에 따른 차이를 확인하기 위하여 단어(word) 수준과 구(phrase) 수준의 과제가 적용되었고, 챈트조건에는 음악요소에 따른 차이를 파 악하기 위해 악센트(세기), 리듬(길이), 악센트+리듬(세기+길 이) 순의 과제가 제시되었다. 녹음에서 대상자는 이러한 8 개의 발화조건에서 각 모음 과제당 4회씩 발화하였고, 녹음 이후 챈 트조건 녹음 과정의 만족도 평가를 위해 설문 응답을 실시하였 다. 챈트 및 읽기 발화 조건은 표 1 과 같다.

표 1. 챈트 및 읽기 발화 조건(8개)

Table 1. Conditions of chanting and reading

\begin{tabular}{|c|c|c|}
\hline \multirow{2}{*}{$\begin{array}{l}\text { 챈트 } \\
\text { (C) }\end{array}$} & $\begin{array}{c}\text { 단어 수 } \\
\text { 준 }\end{array}$ & $\begin{array}{c}\text { 악센트(word_accent, W_A) } \\
\text { 리듬(word_rhythm, W_R) } \\
\text { 악센트+리듬(word_accent\&rhythm, W_AR) }\end{array}$ \\
\hline & $\begin{array}{c}\text { 구 } \\
\text { 수준 }\end{array}$ & $\begin{array}{c}\text { 악센트(phrase_accent, P_A) } \\
\text { 리듬(phrase_rhythm, P_R) } \\
\text { 악센트+리듬(phrase_accent\&rhythm, P_AR) }\end{array}$ \\
\hline \multirow{2}{*}{$\begin{array}{c}\text { 읽기 } \\
(\mathrm{R})\end{array}$} & & 단어 수준(read_citation, R_C) \\
\hline & & 구 수준(read_carrier_phrase, R_CP) \\
\hline
\end{tabular}

\subsection{2. 발화 과제}

읽기 발화 조건에 사용된 녹음 과제는 표 2에 제시하였다. 단 어 수준의 과제는 $\{\mathrm{CV}+\mathrm{CVC}\} 2$ 음절 구조로 구성하였는데, 모 음 삼각도를 이루는 /이/, /아/, /우/ 구석(corner) 모음을 첫 음절 에 위치시키고, 고모음/으/를 두 번째 음절로 하여 포먼트 값에 영향을 미칠 수 있는 음성학적 문맥을 통제하였다. 또한, 어두 초성과 어말 종성에 비음/미를 넣어 조음의 편의성과 챈트 수 행의 용이성을 고려하였다. 최종적으로 현실 내용어에 가까운 ‘미음, 마음, 무음'을 선정하였다. 구 수준의 과제는 틀구문을 사 
용하여 ‘ $\bigcirc \bigcirc$ 이라고 해.'에 위의 단어를 삽입하는 형태로 구조 화하였다. 즉, '미음이라고 해.', ‘마음이라고 해.', ‘무음이라고 해.'의 운반구가 사용되었다. 이에 대해 언어병리학과 석사과정 에 있는 언어재활사 3 명에게 내용타당도 검정을 받았다. 평정 자는 평균 연령 28.3 세 $( \pm 1.1 \mathrm{SD})$ 의 1 급 언어재활사 1 명, 2 급 언어 재활사 2 명으로 평균 임상경력은 5 년 $( \pm 1.1 \mathrm{SD})$ 이었다.

표 2. 읽기 발화 조건 녹음 과제(4회 반복)

Table 2. Recording materials divided into words and phrases (4 repetitions)

\begin{tabular}{c|c}
\hline 단어 수준 & 구 수준 \\
\hline 미음 & 미음이라고 해 \\
\hline 마음 & 마음이라고 해 \\
\hline 무음 & 무음이라고 해 \\
\hline
\end{tabular}

챈트 발화 조건과 관련하여 조음기관의 움직임을 극대화할 수 있을 것으로 예측되는 음악요소로 세기를 반영하는 악센트 (accent)와 음의 길이와 박자를 통해 시간을 조직화하는 리듬 (rhythm)을 선정하였다. 이를 세 수준으로 나누어 '악센트', ‘리 듬, '악센트+리듬'과 같이 구성하였고, 읽기 발화 조건에 사용 된 단어와 운반구를 가사로 사용하였다. 녹음 과제의 예는 표3 에 제시하였다. 챈트 구성에 대한 적절성은 음악중재전문가 (Korean Certified Music Therapist: KCMT) 5명에게 내용타당도 검정을 받았다. 평정자는 평균 연령 36.8 세 $( \pm 1.3 \mathrm{SD})$ 의 음악치료 전공 석사학위 소지자로 평균 임상경력은 7 년 $( \pm 1.7 \mathrm{SD})$ 이었다.
표 3. 챈트 발화 조건 녹음 과제의 예

Table 3. Examples of recording tasks of chanting utterance

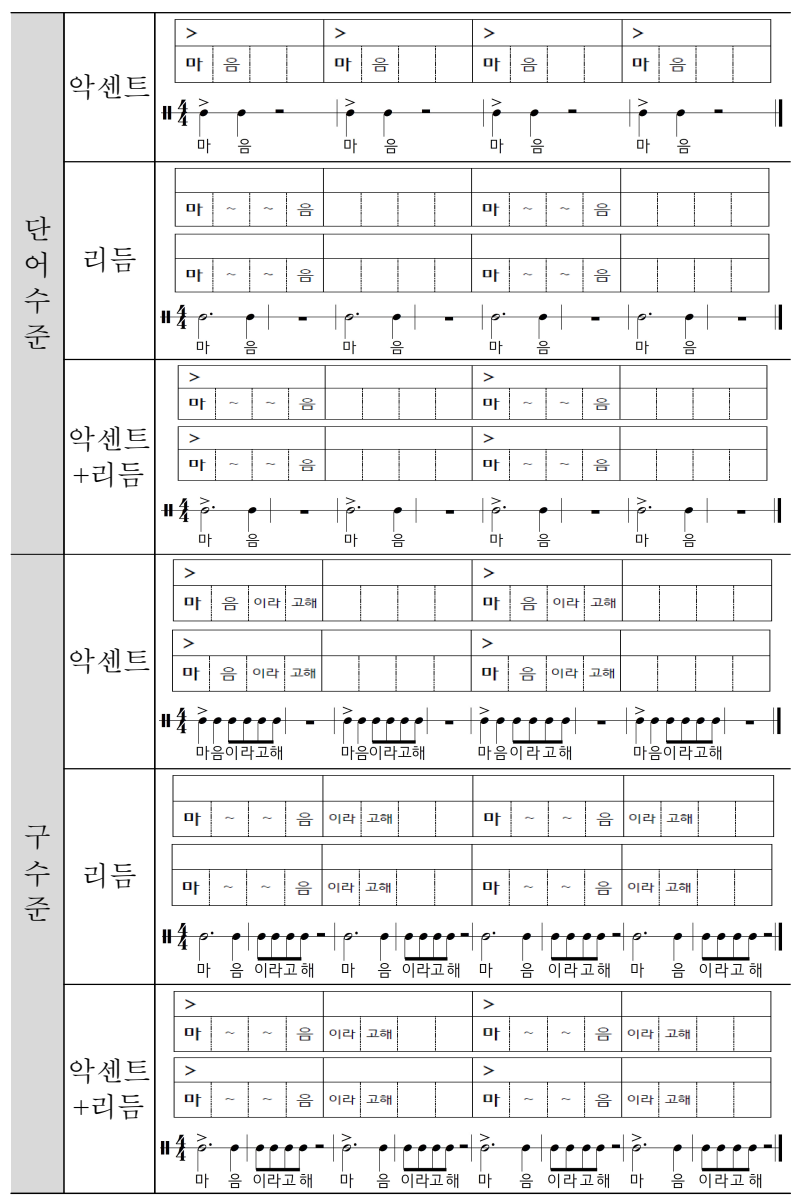

챈트조건 녹음 과정의 만족도를 평가하기 위한 설문지는 총 5 개 문항의 5점 리커트(Likert) 척도로 구성하였다. 문항 내용은 1) 구성된 낱말의 발음 적절성, 2) 챈트 구성 내용의 적절성, 3) 녹음 참여 시간의 적절성, 4) 녹음 참여에 따른 조음의 명확성, 5) 녹음 참여에 따른 즐거움이 포함되었다. 설문지에 대한 내용 타당도는 전문음성학자 1 인이 2 차에 걸쳐 검토하였다. 이를 리 커트(Likert) 척도 $(1=$ 전혀 적절하지 않음, $2=$ 적절하지 않음, $3=$ 보통임, $4=$ 적절함, $5=$ 매우 적절함)로 평정한 결과, 1 번 문항 평 균 4.73점 $( \pm 0.48 \mathrm{SD}), 2$ 번 문항 평균 4.75 점 $( \pm 0.57 \mathrm{SD}), 3$ 번 문항 평균 4.77점 $( \pm 0.59 \mathrm{SD}), 4$ 번 문항 평균 4.62점 $( \pm 0.63 \mathrm{SD}), 5$ 번 문항 평균 4.78점 $( \pm 0.49 \mathrm{SD})$ 을 나타내었다. 설문 응답에 대한 평가자 간 신뢰도(inter-rater reliability, IRR)는 퍼센트 일치도(percent agreement) $95 \%$ 를 기록하였다. 설문 결과는 표 4 , 그림 1 에 제시 하였다. 
표 4. 챈트 녹음과정에 대한 만족도 설문 결과

Table 4. The satisfaction survey result of chant recording process

\begin{tabular}{|c|c|c|c|c|c|c|c|}
\hline \# & 내용 & $\mathrm{N}$ & 1점 & 2점 & 3점 & 4점 & 5점 \\
\hline 1 & $\begin{array}{c}\text { 챈트 구성 낱말의 } \\
\text { 발음 적절성 }\end{array}$ & 60 & & & $\begin{array}{c}1 \\
(1.7 \%)\end{array}$ & $\begin{array}{c}14 \\
(23.3 \%)\end{array}$ & $\begin{array}{c}45 \\
(75.0 \%)\end{array}$ \\
\hline 2 & $\begin{array}{c}\text { 챈트 구성내용의 } \\
\text { 적절성 }\end{array}$ & 60 & & $\begin{array}{c}1 \\
(1.7 \%)\end{array}$ & $\begin{array}{c}1 \\
(1.7 \%)\end{array}$ & $\begin{array}{c}10 \\
(16.7 \%)\end{array}$ & $\begin{array}{c}48 \\
(80.0 \%)\end{array}$ \\
\hline 3 & $\begin{array}{l}\text { 녹음 참여 시간 } \\
\text { (길이)의 적절성 }\end{array}$ & 60 & & $\begin{array}{c}1 \\
(1.7 \%)\end{array}$ & $\begin{array}{c}2 \\
(3.3 \%)\end{array}$ & $\begin{array}{c}7 \\
(11.7 \%)\end{array}$ & $\begin{array}{c}50 \\
(83.3 \%)\end{array}$ \\
\hline 4 & $\begin{array}{l}\text { 녹음 참여에 따른 } \\
\text { 조음의 명확성 }\end{array}$ & 60 & & & $\begin{array}{c}5 \\
(8.3 \%)\end{array}$ & $\begin{array}{c}13 \\
(21.7 \%)\end{array}$ & $\begin{array}{c}42 \\
(70.0 \%)\end{array}$ \\
\hline 5 & $\begin{array}{c}\text { 녹음 참여의 } \\
\text { 즐거움 }\end{array}$ & 60 & & & $\begin{array}{c}2 \\
(3.3 \%)\end{array}$ & $\begin{array}{c}9 \\
(15.0 \%)\end{array}$ & $\begin{array}{c}49 \\
(81.7 \%)\end{array}$ \\
\hline
\end{tabular}

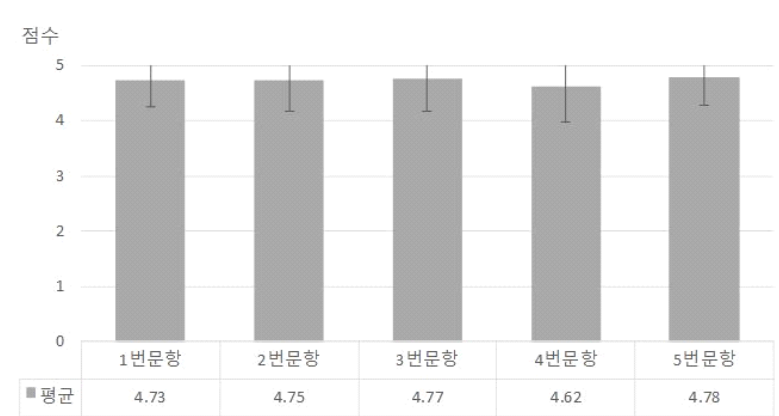

그림 1. 만족도 설문의 평균 및 표준편차

Figure 1. Mean and standard deviation of satisfaction survey

\subsection{3. 자료 분석}

녹음된 자료는 Praat(version 5.3.14, Netherlands) 프로그램을 사용하여 분석하였다. 먼저, 단어, 구문 내 모음/이/,/아/,/우/ 의 안정구간을 분절, 레이블링 한 후 스크립트를 이용하여 자동 측 정하였다. 음향변수는 모음 삼각도 전체가 이동되는 양상, 패턴 을 정량화하기 위해 모음 삼각형 무게중심을 측정하였고, 말명 료도와의 관계를 확인하기 위해 추가적으로 모음 삼각형 면적을 분석하였다. 표 5 는 분석에 사용된 음향변수에 대한 설명이다.

표 5. 음향변수 측정 목록

Table 5. Acoustic variables used in analysis

\begin{tabular}{c|c}
\hline 음향변수 & 내용 \\
\hline 포먼트(formant) & 각 모음의 $F_{1}, F_{2}$ 값 \\
\hline $\begin{array}{c}\text { 모음 삼각형 무게중심 } \\
\text { (center of gravity) }\end{array}$ & 모음 삼각도의 이동 양상을 보여줌 \\
\hline $\begin{array}{c}\text { 모음 삼각형 면적 } \\
\text { (vowel space area, VSA) }\end{array}$ & $\begin{array}{c}\text { 모음 삼각도 내 공간 면적. } \\
\text { 맘명령로고와리를 퐌련하여 해하역함 }\end{array}$ \\
\hline
\end{tabular}

포먼트 측정 세팅은 Park \& Seong (2019)의 최적 스크립트를 원용하여 최대 포먼트와 포먼트 개수를 모음 유형과 성별에 따 라 다르게 설정하여 자동 측정하였고, 모음 삼각형 무게중심 (center of gravity)과 모음 삼각형 면적(vowel space area, VSA)은 아래 공식에 따라 산출하였다(표 6).
표 6. 음향 파라미터 공식 및 측정 세팅 값 Table 6. Formulas for acoustic parameters and related settings

\begin{tabular}{|c|c|}
\hline $\begin{array}{l}\text { 포먼트 } \\
\text { 측정 세팅 }\end{array}$ & $\begin{array}{l}\text { - 최대 포먼트 주파수 }(\mathrm{Hz}) / \text { 설정개수 } \\
\text { /이/: 남성 }(4,950 / 5.25), \text { 여성 }(5,400 / 4.5) \\
\text { /아/: 남성 }(5,400 / 5.5), \text { 여성 }(4,300 / 5) \\
\text { /우/: 남성 }(4,050 / 5.5), \text { 여성 }(4,400 / 5.5)\end{array}$ \\
\hline $\begin{array}{c}\text { 모음 삼각형 } \\
\text { 무게중심 }\end{array}$ & 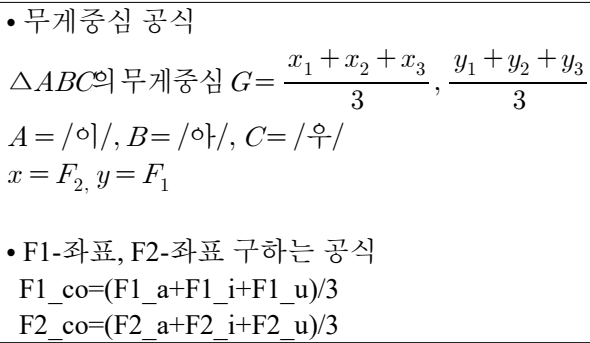 \\
\hline $\begin{array}{c}\text { 모음 삼각형 } \\
\text { 면적 }\end{array}$ & 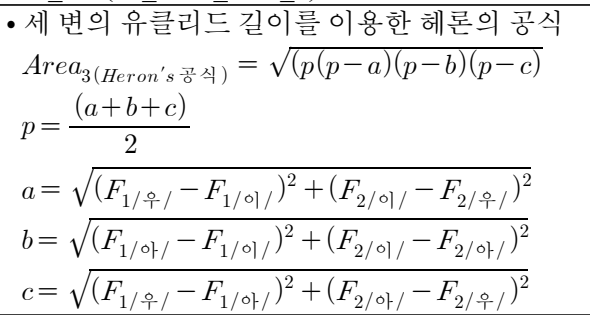 \\
\hline
\end{tabular}

\section{3. 통계 분석}

통계 분석은 SPSS(version 23, IBM, USA) 프로그램을 사용하 였다. 챈트 및 읽기 발화 조건에 따른 모음의 음향학적 특성을 비교하기 위해 음향변수를 종속변수로 하고, 각 모음 당 4회씩 발화한 반복회차를 무선변수(random factor)로, 8 개의 발화조건 과 성별을 고정변수(fixed factor)로 설정하였다. 이에 반복회차× 성별×발화조건으로 이루어진 혼합모형 3원 분산분석(mixed effect 3-way ANOVA)을 실시하였다. 사후검정 시 다중비교로 인한 1종오류는 Bonferroni 조정으로 통제하였다.

\section{3. 연구 결과}

\section{1. 포먼트 비교}

성별과 발화 조건에 따른 모음별 $F_{1}$ 기술통계표를 표 7에 제 시하였다. 
표 7. 성별과 발화조건에 따른 모음별 $F_{1}$ 값

Table 7. Descriptive statistics of $F_{1}$ for three vowels according to gender and utterance conditions

\begin{tabular}{|c|c|c|c|c|c|}
\hline 성별 & 발호 & 화조건 & $F_{1}$ /이/ & $F_{1} /$ 아/ & $F_{1} /$ 우/ \\
\hline \multirow{8}{*}{ 남 } & \multirow{6}{*}{ 챈트 } & W_A & $371.44( \pm 52.44)$ & $757.39( \pm 56.48)$ & $450.94( \pm 64.14)$ \\
\hline & & W R & $361.12( \pm 77.45)$ & $673.08( \pm 88.21)$ & $408.65( \pm 550.23)$ \\
\hline & & W_AR & $383.31( \pm 56.79)$ & $705.32( \pm 74.70)$ & $427.16( \pm 53.44)$ \\
\hline & & P_A & $391.74( \pm 62.28)$ & $754.96( \pm 65.90)$ & $452.15( \pm 82.85)$ \\
\hline & & P_R & $369.58( \pm 53.55)$ & $677.94( \pm 81.76)$ & $404.38( \pm 45.09)$ \\
\hline & & P_AR & $395.76( \pm 61.67)$ & $707.68( \pm 58.71)$ & $436.83( \pm 64.51)$ \\
\hline & \multirow{2}{*}{ 읽기 } & R_C & $293.26( \pm 28.95)$ & $707.90( \pm 84.25)$ & $349.03( \pm 31.04)$ \\
\hline & & R_CP & $294.35( \pm 25.15)$ & $680.52( \pm 97.53)$ & $341.37( \pm 27.88)$ \\
\hline \multirow{8}{*}{ 여 } & \multirow{6}{*}{ 챈트 } & W_A & $503.05( \pm 122.88)$ & $1,056.98( \pm 121.94)$ & $617.63( \pm 68.67)$ \\
\hline & & W_R & $446.03( \pm 89.90)$ & $856.74( \pm 145.40)$ & $511.10( \pm 97.04)$ \\
\hline & & W_AR & $494.98( \pm 131.64)$ & $948.16( \pm 133.01)$ & $571.68( \pm 73.10)$ \\
\hline & & $\mathrm{PA} A$ & $531.99( \pm 128.13)$ & $1,048.88( \pm 146.22)$ & $610.03( \pm 75.02)$ \\
\hline & & P_R & $484.98( \pm 96.24)$ & $862.58( \pm 125.37)$ & $486.25( \pm 103.14)$ \\
\hline & & $P \_A R$ & $520.46( \pm 119.78)$ & $947.27( \pm 119.54)$ & $563.80( \pm 889.05)$ \\
\hline & \multirow{2}{*}{ 읽기 } & R_C & $344.98( \pm 35.78)$ & $937.83( \pm 107.65)$ & $386.83( \pm 46.87)$ \\
\hline & & $\mathrm{R} \mathrm{CP}$ & $349.18( \pm 34.80)$ & $921.38( \pm 89.77)$ & $390.44( \pm 42.23)$ \\
\hline
\end{tabular}

표 8은 혼합모형 3원 분산분석(mixed effect 3-way ANOVA)으 로 검정한 결과다. 발화조건, 성별, 반복회차에 따른 $F_{1}$ 분석 결 과, 무선 변수인 반복회차는 모음 /이/, /아/, /우/ 모두에서 유의 한 차이가 없었다. 발화조건과 성별 주효과는 모든 모음에서 관 찰되었고, 발화조건과 성별 간 상호작용 효과도 모음 /이/[F(7, $21)=80.72, p<.0001], /$ 아 $/[F(7,21)=24.60, p<.0001], /$ 우 $/[F(7,21)=$ 84.46, $p<.0001]$ 에서 관찰되었다. 상호작용의 유형이 주효과의 다중 중첩 패턴으로 표현되는 순차 상호작용(ordinal interaction) 이었다(Widaman et al., 2012). 순차 상호작용이 관찰된 경우는 주효과 보고가 필요하다. 무선변수가 유의하지 않으므로 두 고 정변수의 상호작용 해석으로 진행하면 된다. 상호작용을 해석 하기 위하여 본페로니 교정이 적용된 다중 짝대응(multiple pairwise comparison)을 실시하였다. SPSS의 순수 메뉴 기반 접 근으로는 모든 대응 짝의 유의확률값이 나오지는 않으므로 통 계 script를 직접 코딩하여 모든 대응짝의 유의확률값이 나타나 는 짝대응 테이블을 구하였다(이하 동일한 방법 적용).

표 8. $F_{1}$ 에 대한 혼합모형 3 원 분산분석 결과

Table 8. The result of mixed effect 3 -way ANOVA test for $F_{1}$

\begin{tabular}{|c|c|c|c|c|}
\hline 모음 & & $d f$ & $F$-value & Sig. \\
\hline \multirow{4}{*}{ /이/ } & 발화조건 & 7 & 769.56 & $.000^{* * * *}$ \\
\hline & 성별 & 1 & $1,912.51$ & $.000^{* * * *}$ \\
\hline & 반복회차 & 3 & .49 & .71 \\
\hline & 발화조건×성별 & 7 & 80.72 & $.000^{* * *}$ \\
\hline \multirow{4}{*}{ /아/ } & 발화조건 & 7 & 156.35 & $.000^{* * *}$ \\
\hline & 성별 & 1 & $29,835.00$ & $.000^{* * * *}$ \\
\hline & 반복회차 & 3 & 20.67 & .49 \\
\hline & 발화조건 $\times$ 성별 & 7 & 24.60 & $.000^{* * *}$ \\
\hline \multirow{4}{*}{ /우/ } & 발화조건 & 7 & 469.29 & $.000^{* * * *}$ \\
\hline & 성별 & 1 & $3,895.80$ & $.000^{* * *}$ \\
\hline & 반복회차 & 3 & 1.31 & .39 \\
\hline & 발화조건×성별 & 7 & 84.46 & $.000^{* * *}$ \\
\hline
\end{tabular}

다음은 이 짝대응을 구하기 위한 SPSS Syntax code다.

UNIANOVA fl BY $\mathrm{m}$ _condition gender vowel_ $\mathrm{j}$

/RANDOM=vowel $\_\mathrm{j}$

/METHOD=SSTYPE(3)

$/$ INTERCEPT $=$ INCLUDE

$/$ POSTHOC $=\mathrm{m}$ _condition(TUKEY)

$/$ EMMEANS=TABLES(OVERALL)

/EMMEANS=TABLES(m condition) COMPARE ADJ(BONFERRONI) /EMMEANS=TABLES(gender) COMPARE ADJ(BONFERRONI)

/EMMEANS=TABLES(vowel_j) COMPARE ADJ(BONFERRONI)

/EMMEANS=TABLES(m_condition*gender) COMPARE(m_condition) ...ADJ(BONFERRONI)

/EMMEANS=TABLES(m_condition $\times$ gender) COMPARE(gender)

... ADJ(BONFERRONI)

/PRINT=ETASQ HOMOGENEITY DESCRIPTIVE

/CRITERIA=ALPHA(.05)

$/ \mathrm{DESIGN}=\mathrm{m} \_$condition vowel $\mathrm{j} \mathrm{m} \_$condition $\times$vowel $\mathrm{j}$.

$F_{1}$ 에 대해 본페로니 사후검정을 실시한 결과 챈트조건과 읽 기조건 비교 시 남성의 경우, 모음 /이/에서는 모든 챈트조건과 읽기조건 간에 유의미한 차이가 있었고 $(p<.0001)$, 모음 /아/에서 는 악센트를 포함한 챈트조건 'W_A, P_A'와 모든 읽기조건 간 에 유의미한 차이가 있었으며( $p<.05)$, 모음/우/에서는 모든 챈 트조건과 읽기조건 간에 유의미한 차이가 있었다 $(p<.0001)$. 한 편 여성의 경우, 모음/이/에서는 모든 챈트조건과 읽기조건 간 에 유의미한 차이가 있었고( $p<.0001)$, 모음/아/에서는 악센트를 포함한 챈트조건 'W_A, P_A'와 모든 읽기조건 간에 유의미한 차이가 있었으며 $(p<.0001)$, 모음/우/에서는 모든 챈트조건과 읽 기조건 간에 유의미한 차이가 있었다 $(p<.0001)$. 단어와 구 수준 간에는 남녀 모두 차이가 없었다. 표 9는 성별과 발화 조건에 따 른 모음별 $F_{2}$ 기술통계표다.

표 9. 성별과 발화조건에 따른 모음별 $F_{2}$ 값

Table 9. Descriptive statistics for $F_{2}$ for three vowels according to gender and utterance conditions

\begin{tabular}{|c|c|c|c|c|c|}
\hline $\begin{array}{l}\text { 성 } \\
\text { 별 }\end{array}$ & \multicolumn{2}{|c|}{ 발화조건 } & $F_{2} /$ 이/ & $F_{2}$ _아/ & $F_{2}$ /우/ \\
\hline \multirow{8}{*}{ 남 } & & W_A & $2,098.57( \pm 236.93)$ & $1,243.43( \pm 104.72)$ & $1,029.53( \pm 112.10)$ \\
\hline & & W_R & $2,042.49( \pm 422.37)$ & $1,196.14( \pm 155.43)$ & $984.15( \pm 114.77)$ \\
\hline & 챈 & W_AR & $2,045.01( \pm 405.17)$ & $1,235.13( \pm 143.81)$ & $1,005.52( \pm 117.48)$ \\
\hline & EE & P_A & $2,112.39( \pm 280.68)$ & $1,241.65( \pm 113.36)$ & $11,039.08( \pm 133.94)$ \\
\hline & & P_R & $2,018.16( \pm 446.26)$ & $1,191.23( \pm 170.77)$ & $1,003.31( \pm 118.96)$ \\
\hline & & P_AR & $2,091.02( \pm 361.69)$ & $1,241.22( \pm 121.76)$ & $1,004.97( \pm 156.62)$ \\
\hline & 읽 & R_C & $2,083.71( \pm 206.16)$ & $1,131.18( \pm 160.18)$ & $890.10( \pm 120.24)$ \\
\hline & 기 & R_CP & $2,025.82( \pm 204.20)$ & $1,106.83( \pm 156.62)$ & $887.91( \pm 95.68)$ \\
\hline \multirow{8}{*}{ 여 } & & W_A & $2,793.27( \pm 219.59)$ & $1,580.15( \pm 159.49)$ & $1,126.68( \pm 196.76)$ \\
\hline & & W_R & $2,866.46( \pm 127.69)$ & $1,485.99( \pm 221.19)$ & $999.38( \pm 246.11)$ \\
\hline & & W_AR & $2,847.17( \pm 231.09)$ & $1,535.98( \pm 183.28)$ & $1,097.39( \pm 216.31)$ \\
\hline & EE & P_A & $2,833.11( \pm 142.26)$ & $1,602.12( \pm 138.72)$ & $1,131.42( \pm 221.19)$ \\
\hline & & P_R & $2,846.93( \pm 230.96)$ & $1,444.97( \pm 251.53)$ & $1,035.63( \pm 271.76)$ \\
\hline & & P_AR & $2,866.74( \pm 135.14)$ & $1,544.59( \pm 184.79)$ & $1,070.96( \pm 220.65)$ \\
\hline & 읽 & R_C & $2,778.56( \pm 143.06)$ & $1,443.83( \pm 127.36)$ & $960.61( \pm 140.63)$ \\
\hline & 기 & R_CP & $2,738.47( \pm 156.23)$ & $1,420.83( \pm 131.63)$ & $956.48( \pm 129.29)$ \\
\hline
\end{tabular}


발화조건, 성별, 반복회차에 따른 $F_{2}$ 에 대해 혼합모형 3 원 분 산분석(mixed effect 3-way ANOVA)으로 검정한 결과를 표 10에 제시하였다. 분석결과, 무선 변수인 반복회차는 모음 /이 $/(p=.441), /$ 아/ $(p=.656), /$ 우/ $(p=.312)$ 모두에서 유의한 차이가 없 었고 발화조건과 성별 간 상호작용 효과가 모음 /이/[F(7, 21)= $10.20, p<.001], /$ 아 $/[F(7,21)=4.54, p<.01], /$ 우 $/[F(7,21)=4.80$, $p<.01]$ 에서 관찰되었다. $F_{1}$ 과 마찬가지로 순차 상호작용이었다. 발화조건 주효과와 성별 주효과가 모든 모음에서 관찰되었다.

표 10. $F_{2}$ 에 대한 혼합모형 3 원 분산분석 결과

Table 10. The result of mixed effect 3-way ANOVA test for $F_{2}$

\begin{tabular}{|c|c|c|c|c|}
\hline 모음 & & $d f$ & $F$-value & Sig. \\
\hline \multirow{4}{*}{ /이/ } & 발화조건 & 7 & 16.47 & $.000^{* * *}$ \\
\hline & 성별 & 1 & $16,848.19$ & $.000^{* * *}$ \\
\hline & 반복회차 & 3 & 2.71 & .44 \\
\hline & 발화조건×성별 & 7 & 10.20 & $.000^{* * * *}$ \\
\hline \multirow{4}{*}{ 1아/ } & 발화조건 & 7 & 56.55 & $.000^{* * * *}$ \\
\hline & 성별 & 1 & $4,343.46$ & $.003^{* *}$ \\
\hline & 반복회차 & 3 & .61 & .66 \\
\hline & 발화조건×성별 & 7 & 4.54 & $.000^{* * * *}$ \\
\hline \multirow{4}{*}{ /우/ } & 발화조건 & 7 & 47.33 & $.000^{* * *}$ \\
\hline & 성별 & 1 & 119.95 & $.002^{* *}$ \\
\hline & 반복회차 & 3 & 1.50 & .31 \\
\hline & 발화조건×성별 & 7 & 4.80 & $.002^{* *}$ \\
\hline
\end{tabular}

$F_{2}$ 에 대해 본페로니 사후검정을 실시한 결과 챈트조건과 읽 기조건 비교 시 남성의 경우, 모음 /이/에서는 모든 챈트조건과 읽기조건 간에 유의미한 차이가 없었고, 모음/아/에서는 악센 트를 포함한 모든 챈트조건 'W_A, W_AR, P_A, P_AR' 과 모든 읽기조건 간에 유의미한 차이가 있었으며 $(p<.01)$, 'W_R, $\mathrm{P} \_$' 과 'R_CP' 간에 유의미한 차이가 있었다 $(p<.01)$. 모음 /우/에서 는 모든 챈트조건과 읽기조건 간에 유의미한 차이가 있었다 ( $p<.0001)$. 한편 여성의 경우, 모음/이/에서는 'W_R, P_AR' 과 'R_CP' 간에 유의미한 차이가 있었고 $(p<.01)$, 모음 /아/에서는 악센트를 포함한 모든 챈트조건 'W_A, W_AR, P_A, P_AR' 과 모든 읽기조건 간에 유의미한 차이가 있었으며 $(p<.0001)$, 모음 / 우/에서는 악센트를 포함한 모든 챈트조건 'W_A, W_AR, P_A, P_AR' 과 모든 읽기조건 간에 유의미한 차이가 있었고 $(p<.0001)$, 'P_R'과 모든 읽기조건 간에 유의미한 차이가 있었다( $p<.05)$. 단 어와 구 수준 간에는 남녀 모두 대부분 차이가 없었다.

\section{2. 모음 삼각형 무게중심 비교}

성별과 발화 조건에 따른 모음/이, 아, 우/의 무게중심 $\mathrm{y}$ 값 ( $F_{1}$ coordinate, $F_{1} \_$co $)$과 x 값 $\left(F_{2}\right.$ coordinate, $F_{2}$ co $)$ 에 대한 기술 통계 결과를 표 11 에 제시하였다.
표 11. 성별과 발화조건에 따른 $F_{1}$ co, $F_{2}$ co 값

Table 11. Descriptive statistics for $F_{1}$ co and $F_{2}$ co according to gender and utterance conditions

\begin{tabular}{|c|c|c|c|c|}
\hline 성별 & \multicolumn{2}{|c|}{ 발화조건 } & $F_{1 \_ \text {co }}$ & $F_{2}$ co \\
\hline \multirow{8}{*}{ 남 } & \multirow{6}{*}{ 챈트 } & W_A & $526.59( \pm 339.72)$ & $1,457.17( \pm 113.69)$ \\
\hline & & W_R & $480.95( \pm 52.51)$ & $1,407.59( \pm 150.23)$ \\
\hline & & W_AR & $505.26( \pm 43.97)$ & $1,428.55( \pm 147.07)$ \\
\hline & & P_A & $532.95( \pm 52.25)$ & $1,464.37( \pm 132.75)$ \\
\hline & & P_R & $483.97( \pm 40.29)$ & $1,404.23( \pm 166.59)$ \\
\hline & & P_AR & $513.42( \pm 43.17)$ & $1,445.74( \pm 135.45)$ \\
\hline & \multirow{2}{*}{ 읽기 } & R_C & $450.06( \pm 29.34)$ & $1,368.33( \pm 97.57)$ \\
\hline & & R_CP & $438.74( \pm 34.72)$ & $1,340.18( \pm 90.93)$ \\
\hline \multirow{8}{*}{ 여 } & \multirow{6}{*}{ 챈트 } & W_A & $725.89( \pm 63.82)$ & $1,833.37( \pm 114.72)$ \\
\hline & & W_R & $604.62( \pm 72.35)$ & $1,783.94( \pm 114.71)$ \\
\hline & & W_AR & $671.61( \pm 74.53)$ & $1,826.85( \pm 123.33)$ \\
\hline & & P_A & $730.30( \pm 68.79)$ & $1,855.55( \pm 98.35)$ \\
\hline & & P_R & $611.27( \pm 69.54)$ & $1,775.85( \pm 140.13)$ \\
\hline & & P_AR & $677.17( \pm 70.97)$ & $1,827.43( \pm 93.32)$ \\
\hline & \multirow{2}{*}{ 읽기 } & R_C & $556.54( \pm 42.38)$ & $1,727.67( \pm 90.47)$ \\
\hline & & R_CP & $553.67( \pm 35.72)$ & $1,705.26( \pm 94.14)$ \\
\hline
\end{tabular}

표 12는 혼합모형 3원 분산분석(mixed effect 3-way ANOVA) 으로 검정한 결과다. 발화조건, 성별, 반복회차에 따른 $F_{1}$ co 분 석결과, 무선 변수인 반복회차는 유의한 차이가 없었고 $(p=.61)$, 발화조건과 성별 간 순차 상호작용 효과가 관찰되었다 $[F(7,21)=$ 97.30, $p<.0001]$. 발화조건 $[F(7,21)=1,012.91, p<.0001]$ 과 성별 $[F(1,3)=35,031.43, p<.0001]$ 주효과도 관찰되었다.

표 12. $F_{1} \operatorname{co}$ 에 대한 혼합모형 3원 분산분석 결과

Table 12. The result of mixed effect 3 -way ANOVA test for $F_{1}$ co

\begin{tabular}{c|c|c|c}
\hline & $d f$ & $F$-value & Sig. \\
\hline 발화조건 & 7 & $1,012.91$ & $.000^{* * *}$ \\
\hline 성별 & 1 & $35,031.43$ & $.000^{* * *}$ \\
\hline 반복회차 & 3 & 21.61 & .65 \\
\hline 발화조건×성별 & 7 & 97.30 & $.000^{* * *}$
\end{tabular}

**** $p<.0001$.

$F_{1} \_$co에 대해 본페로니 사후검정을 실시한 결과 챈트조건과 읽기조건 비교 시 남성의 경우, 모든 챈트조건과 읽기조건 간에 유의미한 차이가 있었고 $(p<.0001)$, 여성의 경우에도 모든 챈트 조건과 읽기조건 간에 유의미한 차이가 있었다 $(p<.0001)$. 단어 와 구 수준 간에는 남녀 모두 차이가 없었다. 성별 비교 시 챈트 조건과 읽기조건을 포함한 8 개의 모든 발화조건에서 남성과 여 성 간에 유의미한 차이가 있었다 $(p<.0001)$.

표 13은 $F_{2}$ co에 대한 혼합모형 3원 분산분석(mixed effect 3-way ANOVA) 검정 결과다. 분석결과, 무선 변수인 반복회차는 유의한 차이가 없었고 $(p=.56)$, 발화조건과 성별 간 상호작용 효과 도 관찰되지 않았다 $(p=.05)$. 발화조건 $[F(7,21)=87.16, p<.0001]$ 과 성별 $[F(1,3)=8,779.76, p<.0001]$ 주효과는 관찰되었다. 
표 13. $F_{2} \operatorname{co}$ 에 대한 혼합모형 3 원 분산분석 결과

Table 13. The result of mixed effect 3-way ANOVA test for $F_{2}$ co

\begin{tabular}{c|c|r|l}
\hline & $d f$ & $F$-value & Sig. \\
\hline 발화조건 & 7 & 87.16 & $.000^{\text {*** }}$ \\
\hline 성별 & 1 & $8,779.76$ & $.000^{* * *}$ \\
\hline 반복회차 & 3 & .77 & .56 \\
\hline 발화조건×성별 & 7 & 2.49 & .05 \\
\hline
\end{tabular}

*** $p<.0001$.

$F_{2}$ co에 대해 본페로니 사후검정을 실시한 결과 챈트조건과 읽기조건 비교 시 남성의 경우, 악센트를 포함한 모든 챈트조건 'W_A, W_AR, P_A, P_AR'과 모든 읽기조건 간에 유의미한 차 이가 있었고( $p<.01)$, ' $\mathrm{W} R, \mathrm{P} \mathrm{R}$ '과 'R CP' 간에 유의미한 차이 가 있었다 $(p<.01)$. 한편 여성의 경우, 악센트를 포함한 모든 챈 트조건 'W_A, W_AR, P_A, P_AR' 과 모든 읽기조건 간에 유의 미한 차이가 있었고 $(p<.0001)$, 'W_R'과 모든 읽기조건, 'P_R' 과 'R_CP' 간에 유의미한 차이가 있었다 $(p<.0001)$. 단어와 구 수준 간에는 남녀 모두 대부분 차이가 없었다. 성별 비교 시 챈트조 건과 읽기조건을 포함한 8 개의 모든 발화조건에서 남성과 여성 간에 유의미한 차이가 있었다( $p<.0001)$

다음은 모음 삼각형 무게중심의 이동양상을 확인할 수 있는 포먼트 모음공간이다. 챈트 발화와 읽기 발화 조건의 비교를 위 해 챈트조건 'W_A'와 읽기조건 'R_CP'를 대비하여 남성의 포 먼트 모음공간을 그림 2 에, 여성의 모음공간을 그림 3 에 제시하 였다. 악센트가 사용된 챈트조건( $\triangle$ 이아우)에서 무게중심의 방 향이 앞쪽, 아래쪽으로 이동한 것을 확인할 수 있다.

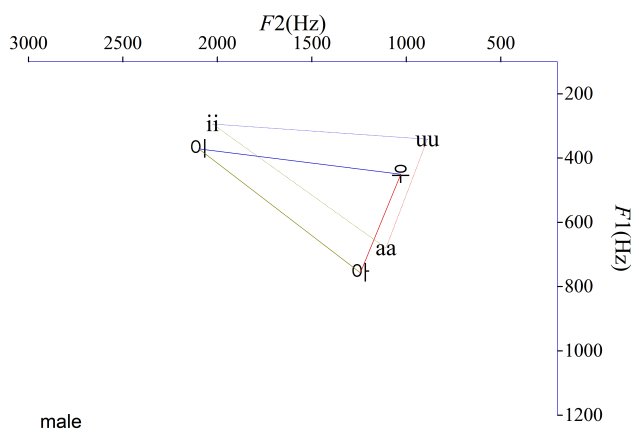

그림 2. 남성 발화조건 ' $\mathrm{W} \_\mathrm{A}$ '와 'R_CP'에 따른 $\triangle /$ 이아우/ 모음 공간

Figure 2. Vowel space showing /iau/_vowel triangle according to 'W_A' and 'R_CP' condition of male utterance

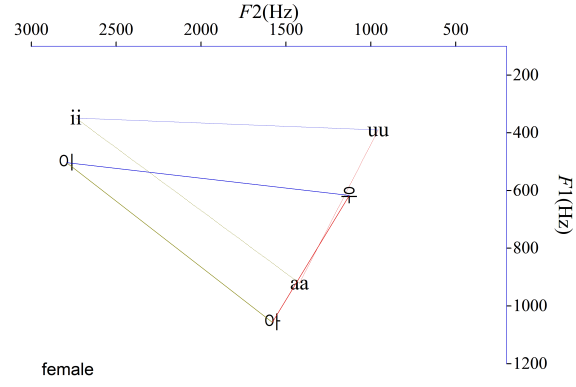

그림 3. 여성 발화조건 'W_A'와 'R_CP'에 따른 $\triangle$ /이아우/ 모음공간

Figure 3. Vowel space showing /iau/_vowel triangle according to 'W_A' and 'R_CP' condition of female utterance

3.3. 모음 삼각형 면적 비교

성별과 발화 조건에 따른 모음/이, 아, 우/의 모음 삼각형 면 적(VSA)에 대한 기술통계표를 표 14에 제시하였다.

표 14. 성별과 발화조건에 따른 VSA 값

Table 14. Descriptive statistics for VSA according to gender and utterance conditions

\begin{tabular}{|c|c|c|c|}
\hline 성별 & \multicolumn{2}{|c|}{ 발화조건 } & VSA \\
\hline \multirow{8}{*}{ 남 } & \multirow{6}{*}{ 챈트 } & W_A & $172,534.58( \pm 53,329.47)$ \\
\hline & & W R & $146,946.38( \pm 73,740.37)$ \\
\hline & & W AR & $153,339.68( \pm 78,490.58)$ \\
\hline & & $\mathrm{PA}$ & $174,596.27( \pm 54,257.80)$ \\
\hline & & $\mathrm{PR}$ & $149,131.21( \pm 71,222.53)$ \\
\hline & & $\mathrm{P}$ AR & $159,268.82( \pm 82,175.63)$ \\
\hline & \multirow{2}{*}{ 읽기 } & R_C & $221,233.70( \pm 71,121.42)$ \\
\hline & & $\mathrm{R} \_\mathrm{CP}$ & $200,126.88( \pm 66,399.80)$ \\
\hline \multirow{8}{*}{ 여 } & \multirow{6}{*}{ 챈트 } & W_A & $397,094.70( \pm 159,763.32)$ \\
\hline & & W_R & $342,144.33( \pm 147,263.84)$ \\
\hline & & W_AR & $345,247.53( \pm 139,262.09)$ \\
\hline & & $\mathrm{P} \_\mathrm{A}$ & $399,571.87( \pm 164,376.10)$ \\
\hline & & P_R & $347,583.22( \pm 159,432.97)$ \\
\hline & & P_AR & $351,026.23( \pm 131,430.64)$ \\
\hline & \multirow{2}{*}{ 읽기 } & R_C & $513,624.01( \pm 116,484.70)$ \\
\hline & & R_CP & $483,366.13( \pm 102,965.61)$ \\
\hline
\end{tabular}

VSA, vowel space area.

표 15는 혼합모형 3 원 분산분석(mixed effect 3-way ANOVA) 으로 검정한 결과다. 발화조건, 성별, 반복회차에 따른 VSA 분 석결과, 무선 변수인 반복회차는 유의한 차이가 없었고 $(p=.76)$, 발화조건과 성별 간 순차 상호작용 효과가 관찰되었으며 $[F(7$, $21)=23.64, p<.0001]$. 발화조건 $[F(7,21)=88.40, p<.0001]$ 과 성별 $[F(1,3)=6,848.38, p<.0001]$ 주효과도 통계적으로 유의한 것으로 나타났다. 
표 15. VSA에 대한 혼합모형 3원 분산분석 결과 Table 15. The result of mixed effect 3-way ANOVA test for VSA

\begin{tabular}{c|c|r|c}
\hline & $d f$ & $F$-value & Sig. \\
\hline 발화조건 & 7 & 88.40 & $.000^{* * *}$ \\
\hline 성별 & 1 & $6,848.38$ & $.000^{* * *}$ \\
\hline 반복회차 & 3 & .41 & .76 \\
\hline 발화조건×성별 & 7 & 23.64 & $.000^{* * *}$ \\
**** $p<.0001$. & \multicolumn{4}{|l}{}
\end{tabular}

${ }^{* * *} p<.0001$

VSA, vowel space area.

$\mathrm{VSA}$ 에 대해 본페로니 사후검정을 실시한 결과 챈트조건과 읽기조건 비교 시 남성의 경우, 챈트조건 'W_R, W_AR, P_R'과 모든 읽기조건, 'W_A, P_A, P_AR'과 'R_C' 간에 유의미한 차이 가 있었다 $(p<.05)$. 한편, 여성의 경우 모든 챈트조건과 읽기조건 간에 유의미한 차이가 있었다 $(p<.0001)$. 단어와 구 수준 간에는 여성에서 차이가 없었고, 남성에서도 대부분 차이가 없었다.

\section{4. 결론 및 논의}

챈트 및 읽기 발화 조건에 따른 모음의 음향학적 특성을 살펴 보았으며 챈트조건 발화 시 읽기조건에 비해 $F_{1}, F_{2}$ 값이 커지고 모음 삼각형 무게중심의 이동 방향이 전방화, 하강화 된다는 것 을 확인하였다. 남성에 비해 여성에서 더 큰 차이를 보였으며, 4 회 반복 발화 간에 유의한 차이를 보이지 않아 결과의 신뢰성을 높였다. 단어와 구 즉 발화 길이에 따른 수준 사이에 차이가 없 었고, 영향을 미치는 음악요소는 악센트였다.

챈트조건과 읽기조건 비교 시 저모음/아/에서 악센트를 포 함한 대부분의 챈트조건 발화가 단어와 구 수준에 상관없이 읽 기 조건에 비해 $F_{1}$ 값이 더 컸다. 이는 악센트를 사용한 챈트가 구강개방을 이루도록 하는 저모음 / 아/의 $F_{1}$ 값 상승에 밀접한 관련이 있음을 알 수 있게 한다. 이와 관련하여 선행연구에서는 구강 개방 제한 상태에서 정상 구강 개방 상태에 비해 말명료도 와 말용인도가 낮으며 특히 저모음의 경우 미치는 영향이 크다 고 하였다(Song, 2011). 따라서 구강 개방을 이루는 조음 훈련에 서 악센트를 활용한 챈트를 사용할 때에 말용인도를 높이는 효 과적인 방법이 될 수 있음을 시사한다. $F_{2}$ 와 관련해서는 후설모 음/아/, /우/에서 악센트를 포함한 대부분의 챈트조건이 읽기조 건에 비해 $F_{2}$ 가 큰 값을 보이며 발화길이에 상관없이 악센트가 혀의 전방화를 이루는데 영향을 미치는 요소임을 확인하였다.

모음 삼각형 무게중심에서는 앞서 설명한 바와 같이 매우 의 미 있는 결과를 나타내었다. 즉, 챈트조건은 발화길이에 상관없 이 $F_{1} \_$co, $F_{2}$ co 값을 크게 하는 변수이며 이에 악센트가 보다 밀접한 관련이 있음을 보여주었다. 연구에서 관찰된 모음 삼각 형 무게중심의 앞쪽, 아래쪽으로 향한 이동양상은 모음 산출 시 구강 내 공간을 적절히 사용하지 못해 혀를 후방화 하거나 적절 한 구강개방을 이루지 못하는 대상자에게 효과적인 중재 방법 의 가능성을 제시한다. 선행연구에 따르면 다양한 대상자는 이 와 관련된 어려움을 호소하는데, 청각장애인의 경우 모음 /아/ 에서 $F_{1}$ 이 낮고 모음 /이/에서 $F_{2}$ 가 낮으며(Oh et al., 2000), 모음
/이-아/, /아-우/, /이-우/ 간 유클리드 거리가 짧다고 보고되고 있 다(Choi \& Seong, 2010). 마비말장애 환자를 대상으로 한 연구에 서는 중도 마비말장애 화자의 경우 음절 수준 분석 결과 $F_{1}$ 이 낮 아 모음사각도의 형태가 $F_{2}$ 축 방향에서 긴 사각도를 보이고, 고 도 마비말장애 화자의 경우에도 $F_{2}$ 가 낮아 모음사각도 형태가 $F_{1}$ 축 방향에서 긴 사각도를 보인다고 하였다(Lee et al., 2010). 또한, 구개열 아동의 경우는 다양한 조음오류 중 조음위치를 극 단적으로 후방화 하는 보상조음을 보일 수 있다(Han \& Sim, 2008). 따라서 이와 같이 조음위치의 전방화, 하방화가 필요한 경우 악센트를 포함한 챈트를 활용하여 적절한 조음위치의 이 동을 유도하도록 도울 수 있을 것으로 보인다.

반면, 모음 삼각형 면적에서 대부분의 챈트조건 발화가 읽기 조건에 비해 VSA값이 작았으며, 발화길이에 따른 차이는 거의 보이지 않았다. 챈트 훈련으로 말명료도가 증가될 것이라 예상 했던 것과는 달리 챈트조건에서 남녀 모두 모음 삼각도 면적이 더 좁게 나타난 것이다. 보통 노래 부르기나 챈트 시에 음높이 에 따라 모음의 중앙화 혹은 중성화가 나타날 수 있음을 고려하 지 못하고 편안한 음높이로 챈트를 수행하도록 한 방법이 이와 같은 결과를 야기한 것으로 짐작된다.

챈트조건 녹음 참여에 따른 만족도 조사 결과 대부분의 항목 에서 높은 점수를 보였는데, 특히 평균 4.78 점 $( \pm 0.48 \mathrm{SD})$ 으로 가 장 높은 점수를 보인 항목은 ‘참여에 따른 즐거움'으로 나타났 다. 이는 노래나 챈트가 영어 학습에서의 자신감과 흥미를 갖게 한다는 $\operatorname{Kim}(2000)$ 의 연구를 지지하며, 영어 교육에 챈트를 도입 한 Graham(1978)의 주장과 같이 챈트에서 사용된 음악요소가 즐거움과 흥미를 더해준다는 것을 보여주었다.

본 연구를 통해 음향변수에 영향을 미치는 챈트 발화의 장단 점을 살펴보았다. 특히, 모음 삼각형 무게중심과 관련하여 악센 트를 포함한 챈트는 웅얼거리는 듯한 발화를 하는 대상자들의 적절한 구강개방을 돕고, 후방화된 조음위치로 인해 오조음을 보이는 이들에게 모음의 무게중심을 전방으로 이동시키는 효 과적인 방법이 될 수 있음을 알게 하였다. 이는 조음의 어려움 이 보고되는 청각장애, 마비말장애, 말소리 장애, 구개열 아동 등에게 적용될 수 있음을 시사하며, 챈트 과정의 즐거움이 참여 동기를 높일 수 있다는 가능성을 나타낸다. 다만, 본 연구에서 는 일반 성인만을 대상으로 분석했다는 제한점이 있어 후속 연 구에서는 실제 조음에 어려움을 보이는 대상으로 분석해보려 고 한다. 모음 삼각형 면적에서 챈트 과제의 면적이 오히려 유 의하게 작았던 점은 음높이 통제가 되지 못한 상태에서 모음의 상대적 중앙화가 나타났기 때문으로 보인다. 추후 연구에서는 이를 고려한 음높이 통제가 이루어져야 할 것으로 보이며, 청지 각적 평가를 통해 음향변수 결과와 말명료도 간의 상관성이 확 인되어야 할 것 같다. 본 연구를 통해 악센트를 포함한 챈트가 모음 조음에 특정 변동을 초래하고 실질적으로 패턴화되는 것 이 관찰되었으나 중재 연구로 설계되지 않은 점은 약점이라 할 수 있다. 


\section{References}

Baker, F., \& Uhlig, S. (2011). Voicework in music therapy: Research and practice. London, UK: Jessica Kingsley Publishers.

Choi, C. H., Choi, S. H., \& Lee, K. J. (2015). Speech science. Seoul, Korea: Sigmapress.

Choi, E., \& Seong, C. (2010). The articulation characteristics of the profound hearing-impaired adults' Korean monophthongs: With reference to the F1, F2 of acoustic vowel space. Phonetics and Speech Sciences, 2(4), 229-238.

Chung, H. J., Kim, Y. S., Choi, M. H., Jo, H. J., Noh, J. H., Kim, D. M., Kim, J. A., ... Austin, D. (2006). Music therapy techniques and models. Seoul, Korea: Hakjisa.

Cohen, N. S. (1992). The effect of singing instruction on the speech production of neurologically impaired persons. Journal of Music Therapy, 29(2), 87-102.

Eom, S. H., \& Shin, H. J. (2018). A study on vowel space area and speech intelligibility in children with articulation disorder. Journal of Speech, Language, and Hearing Research, 27(1), 115-126.

Fry, D. B. (1982). The physics of speech. Cambridge, UK: Cambridge University Press.

Graham, C. (1978). Jazz chant for children. New York, NY: Oxford University Press.

Han, J. S., \& Sim, H. S. (2008). Comparisons of the percentage of correct consonants, speech intelligibility, and speech acceptability among children with cleft palate, children with functional articulation disorder, and normally developing children. Korean Journal of Communication Disorders, 13(3), 454-476.

Hong, S. H., Na, S. Y., \& Kwon, Y. H. (2010). A study on the elementary school students' preference about english songs and chants. The Journal of Korea Elementary Education, 21(1), 135146.

Howard, S., \& Lohmander, A. (2011). Cleft palate speech: Assessment and intervention. Hoboken, NJ: John Wiley \& Sons.

Kang, B. M. (2005). Language. Seoul: Hankook Publishing House.

Kim, J., \& Seong, C. (2016). The change of vowel characteristics for the dysarthric speech along with speaking style. Phonetics and Speech Sciences, 8(3), 51-59.

Kim, M. (2014). Cases with speech sound disorders assimilating plosives and nasals to various vowel features. Communication Sciences \& Disorders, 19(4), 532-539.

Kim, M. S. (2000). Effect of chants and songs on elementary school English learning. Studies in English Education, 5(2), 79-103.

Kim, S. J., \& Shin, J. Y. (2015). Speech sound disorders. Seoul, Korea: Sigmapress.

Kummer, A. W. (2007). Cleft palate \& craniofacial anomalies: Effects on speech and resonance (2nd ed.). Stamford, CT: Cengage Learning.
Kwon, E. K., \& Sim, H. S. (2001). A case study on the speech sound therapy using children's songs: With respect to word-meial / ᄅ/ . Korean Journal of Communication Disorders, 6(2), 498-509.

Lee, O. B., Han, J. Y., \& Park, S. H. (2010). Speech intelligibility in syllables and vowel space according to dysarthric severity. Phonetics and Speech Sciences, 2(2), 85-92.

Oh, Y. J., Zhi, M. Z., \& Kim, Y. T. (2000). Acoustic comparisons of vowel and plosive productions between the normal and the hearing-impaired children. Speech Sciences, 7(2), 51-70.

Park, J. \& Seong, C. (2019). The implementation of Korean adult's optimal formant setting by Praat scripting. Phonetics and Speech Sciences, 11(4), 97-108.

Seong, C. J. (2004). An acoustic analysis on the Korean 8 monophthongs; with respect to the acoustic variables on the $F_{1} / F_{2}$ vowel space. The Journal of the Acoustical Society of Korea, 23(6), 454-461.

Song, Y. K. (2011). Characteristics of speech intelligibility and speech acceptability connected with mouth opening condition. Journal of Phonetics and Speech Sciences, 3(3), 141-148.

Tamplin, J., \& Denise, G. (2008). A music therapy treatment protocol for acquired dysarthria rehabilitation. Music Therapy Perspectives, 26(1), 23-29.

Widaman, K., Helm, J., Castro-Schilo, L., Pluess, M., Stallings, C., \& Belsky, J. (2012). Distinguishing ordinal and disordinal interactions. Psychological Methods, 17(4), 615-622.

\section{- 박지혜 (Jihye Park)}

봄비와씨앗 언어학습심리센터 강사

세종시 한누리대로 2016,503 호

Tel: 044-867-1360

Email: jhparkmt@gmail.com

관심분야: 말장애, 분절음 분석

- 성철재 (Cheoljae Seong) 교신저자

충남대학교 언어학과 교수

대전 유성구 대학로 99

Tel: 042-821-6395

Email: cjseong49@gmail.com 관심분야: 분절음 및 운율분석 


\title{
챈트 및 읽기 발화조건에 따른 한국어 모음 포먼트 비교*
}

\author{
박 지 혜 ${ }^{1}$ 성 철 재 ${ }^{2}$ \\ ${ }^{1}$ 봄비와씨앗 언어학습심리센터, ${ }^{2}$ 충남대학교 언어학과
}

\begin{abstract}
국문초록
모음의 조음은 발화 시 자음과 결합하여 인접한 자음의 조음에 영향을 미칠 수 있기 때문에 정확한 조음위치를 형 성하고 적절한 구강개방을 이루는 것이 중요하나 언어병리 분야의 다양한 대상자들은 이에 어려움을 보인다. 따라 서 이들을 위한 치료를 위해서 언어의 특성을 적절히 반영하고 있는 노래(챈트)가 효과적인 도구로 사용될 수 있다. 본 연구에서는 챈트조건과 읽기조건에 따른 모음 특성을 비교하여 챈트조건이 모음 발화 강화의 수단으로 적절한 지를 알아보고자 하였다. 연구 대상은 한국어를 모국어로 하는 20 30대 일반 성인 60명(남 30명, 여 30명)이었으며, 모음/이/, /아/, /우/가 포함된 챈트 및 읽기 과제를 각 4회씩 반복 발화하도록 하여 녹음한 뒤 음성 자료를 분석하였 다. 음향 변수를 분석한 결과, 읽기조건과 비교해 챈트조건 발화에서 $F_{1}, F_{2}$ 값이 더 커지고, 모음 삼각형 무게중심 의 이동 방향이 전방화, 하강화 된다는 의미 있는 결과를 확인하였다. 남녀 비교 시 여성의 값이 유의하게 컸고, 4 회 반복 발화 간에 차이를 보이지 않아 결과의 신뢰도를 높였다. 발화조건 중 단어 수준과 구 수준에 따른 차이는 대부 분 보이지 않았으며, 챈트조건의 음악요소에는 악센트가 영향을 미치는 것으로 나타났다. 이와 같은 결과는 챈트 의 사용이 웅얼거리는 듯한 발화를 하는 대상자들에게 적절한 구강개방을 이루도록 도울 수 있으며, 후방화된 조 음 위치로 인해 오조음을 보이는 이들에게 모음의 무게중심을 이동시키는 효과적인 방법이 될 것임을 시사한다.
\end{abstract}

핵심어: 모음 포먼트, 모음 삼각형 무게중심, 챈트

\section{참고문헌}

강범모(2005). 언어. 서울: 한국문화사.

권은경, 심현섭 (2001). 동요를 이용한 조음음운치료 사례연구. 언어청각장애연구, 6(2), 498-509.

김명식 (2000). 노래와 챈트가 초등영어학습에 미치는 효과에 관

한 연구. Studies in English Education, 5(2), 79-103.

김수진, 신지영 (2015). 말소리장애. 서울: 시그마프레스.

김지연, 성철재 (2016). 경도 마비말장애 환자의 발화 유형에 따

른 모음 특성 비교. 말소리와 음성과학, 8(3), 51-59.

박지연, 성철재 (2019). 성인 포먼트 측정에서의 최적 세팅 구현:

Praat software와 관련하여. 말소리와 음성과학, 11(4), 97-108. 성철재 (2004). 한국어 단모음 8개에 대한 음향분석: F1.F2 모음 공간에서 음향변수를 중심으로. 한국음향학회지, 23(6), 454461.

송윤경 (2011). 구강 개방 상태에 따른 말 명료도 및 말 용인도 특 성. 말소리와 음성과학, 3(3), 141-148.

엄선화, 신혜정 (2018). 조음장애아동의 모음공간면적과 말명료 도 연구. 언어치료연구, 27(1), 115-126.
이옥분, 한지연, 박상의 (2010). 마비말장애 심각도에 따른 음절 단위 말명료도와 모음공간. 말소리와 음성과학, 2(2), 85-92. 정현주, 김영신, 최미환, 조혜진, 노주희, 김동민, 김진아 ... Austin, D. (2006). 음악치료 기법과 모델. 서울: 학지사.

최철희, 최성희, 이경재 (2015). 말과학. 서울: 시그마프레스. 최은아, 성철재 (2010). 심도 청각장애 성인의 한국어 단모음 조 음 특성: 모음 음향 공간의 F1, F2 값을 중심으로. 말소리와 음 성과학, 2(4), 229-238.

한진순, 심현섭 (2008). 구개열 아동과 일반 아동 및 기능적 조음 장애 아동의 자음정확도, 말 명료도 및 말 용인도 비교. 언어청 각장애연구, 13(3), 454-476.

\footnotetext{
* 이 논문은 제 1 저자의 2020 년도 석사학위 논문을 수정, 보완한 것입니다.
} 